\title{
Income and happiness across Europe: Do reference values matter?
}

\author{
Guglielmo Maria Caporale ${ }^{\mathrm{a}}$ \\ Yannis Georgellis ${ }^{\mathrm{a}}$ \\ Nicholas Tsitsianis ${ }^{\mathrm{b}}$ \\ Ya Ping Yin ${ }^{\mathrm{b}}$ \\ ${ }^{a}$ Brunel University, London \\ ${ }^{b}$ University of Hertfordshire
}

May 2007

\begin{abstract}
Using data from the European Social Survey (ESS), we examine the link between income and subjective well-being. We find that, for the whole sample of nineteen European countries, although income is positively correlated with both happiness and life satisfaction, reference income exerts a negative effect on individual well-being, a result consistent with the relative utility hypothesis. Performing separate analyses for some Eastern European countries, we also find some evidence of a 'tunnel effect', in that reference income has a positive impact on subjective well-being. Our findings support the view that in environments with stable income and employment, reference income serves as a basis for social comparisons, whereas in relatively volatile environments, it is used as a source of information for forming expectations about future status.
\end{abstract}

JEL classification: I31

PsycINFO classification: 3100 Personality Psychology

Keywords: Comparison income; Reference groups; Happiness; Life satisfaction.

Corresponding author: Professor Guglielmo Maria Caporale, Centre for Empirical Finance, Brunel University, Uxbridge, Middlesex UB8 3PH, UK. Tel.: +44 (0)1895 266713. Fax: +44 (0)1895 269770. Email: Guglielmo-Maria.Caporale@brunel.ac.uk 


\section{Income and happiness across Europe: Do reference values matter?}

\section{Introduction}

Whether income can buy happiness remains one of the most vexed and fundamental issues in economics and the social sciences in general. Whilst philosophers have debated on what happiness is and how to pursue it for thousands of years, in modern economic theory, economists have focused on approximate measures of happiness and its relationship with measurable socio-economic and demographic variables. Although neoclassical economic theory portrays utility or wellbeing as synonymous to consumption and absolute income, the notion of relative utility could be traced back to the works of Adam Smith, Karl Marx, Veblen, and Duesenberry, and it is, once again, receiving considerable attention in the recent economic literature.

Some early empirical evidence that real income growth does not necessarily imply higher reported happiness levels is provided in the seminal work of Easterlin (1974). This finding has received further support from numerous subsequent studies (see, for example, Heady, 1991; Diener, et. al., 1993; Frey and Stutzer, 2000; Easterlin, 2001; van Praag and Ferrer-i-Carbonell, 2004). By and large, such studies confirm that, despite the growth in real incomes in industrialized countries, happiness levels remained "flat" - this is known as the Easterlin Paradox (Easterlin, 1995). However, a number of recent studies conclude that income can, after all, buy happiness, especially in Eastern European countries (e.g., Frijters et al., 2004).

One possible explanation for these recent findings, which appear at first sight to contradict the Easterlin Paradox, is that relative, instead of absolute income, is what determines utility. How individuals feel about their income depends on their income relative to others around them, rather than their absolute income per se. Indeed, social 
norms, social comparisons, and reference values influence individuals' subjective evaluation of their economic situation, weakening the relationship between income and happiness one could observe based only on absolute income. As Clark and Oswald (1996) show, using regression analysis and controlling for standard individual and demographic characteristics, utility depends on income relative to some reference or comparison income, based on the predicted income of 'people like you'. Defining the reference group to include those with similar education, similar age and living in the same region, Ferrer-I-Carbonell (2005) finds that income of the reference group is as important as own income for individuals' happiness. McBride (2001) uses all those in the same age group, within 5 years younger or older than the individual concerned, while Easterlin (1995) implicitly assumes that individuals compare themselves with all the other citizens of the same country. In an earlier study, Van de Stadt et al. (1985) define the reference group according to education level, age and employment status. Rizzo and Zeckhauser (2003) and Mas (2006) are notable examples of recent studies highlighting the importance of reference points as determinants of actual behavior.

An alternative explanation focuses on individuals' comparisons with their own income or economic situation in the past. As Easterlin (2001) argues, individuals adapt to their economic circumstances so that changes in income have only transitory effects on well-being. This is consistent with a large body of research in psychology providing evidence of adaptation, following Brickman and Campbell's (1971) 'hedonic treadmill' hypothesis. Although Van Praag (1971) and Van Praag and Kapteyn (1973) were the first economists to explore this hypothesis, or, as they called it, the "preference drift" phenomenon, the notion of adaptation was not embraced with the same enthusiasm in the economics literature. Nevertheless, there is an increasing 
consensus that understanding the process of adaptation and changing aspirations is important for our understanding of economic behaviour (see Kahneman and Krueger, 2006. ${ }^{1}$ Recent evidence by Stutzer (2004) shows that higher income aspirations, influenced by both individuals' past income and the average income in their community, reduce utility. Interestingly, Easterlin (2005) also finds that aspirations about economic wealth and other pecuniary aspects of one's well-being tend to change with the level of actual circumstances, suggesting almost complete adaptation. ${ }^{2}$ Clark et al. (2006) provide a comprehensive and insightful review of the main issues in the debate about the relationship between income and happiness.

The study by Rojas (2007) is particularly notable, as it explains the weak relationship between income and happiness using the conceptual-referent theory of happiness (CRT). According to CRT, individuals have different notions about what a happy life is and, therefore, different evaluations of their subjective well-being. As Rojas argues, this heterogeneity in beliefs about a happy life extends to the relationship between income and happiness. A weak relationship between income and happiness may be explained partially by the fact that income might be less important for individuals with conceptual referents for happiness with an inner orientation, as opposed to an outer orientation. ${ }^{3}$

In this paper, we use data from the first two waves of the European Social Survey (ESS) to examine the link between income and subjective well-being, as measured by self-reported happiness and life satisfaction scores, across 19 European

\footnotetext{
${ }^{1}$ The influence of past values of income and consumption on current levels of consumption or utility has also been incorporated into the recent main-stream economic literature on habit formation in investor and consumer behaviour (e.g., Abel, 1990; Campbell and Cochrane, 1999; Fuhrer, 2000).

${ }^{2}$ In contrast, Easterlin (2005) finds that this is not the case with marriage, number of children and other non-pecuniary aspects of one's life.

${ }^{3}$ As Rojas (2007, p. 12) points out, individuals with an inner orientation tend to accept things as they are (stoicism), acting properly in their relations with others and with themselves, living a tranquil life, not looking beyond what is attainable.
} 
countries. While many studies assume happiness and life satisfaction to be synonymous, there is a considerable body of literature showing that measures of happiness and satisfaction are not strongly correlated (see Cummings, 1998). ${ }^{4}$ In general, life satisfaction refers to cognitive states of consciousness, whereas happiness is emotional and mainly concerns intimate matters of life. Indeed recent evidence (e.g., Gundelach and Kreiner, 2004) reinforces Michalos's (1991) view that while happiness and satisfaction form part of a subjective well-being construct, it is heuristically useful to measure and analyse them separately.

After controlling for standard personal and demographic characteristics, our emphasis is on assessing whether social comparisons and reference groups exert a significant influence on individuals’ subjective well-being. Perhaps not surprisingly, we find that absolute income has a positive effect on both happiness and life satisfaction. Nevertheless, we also find that such a relationship weakens when we include an individual's reference income as an explanatory variable. Using two different operational definitions of reference income, we find that this has a negative impact on subjective well-being for the nineteen European countries as a whole. In this respect, our results provide additional support to the idea of relative utility and the importance of reference groups in influencing subjective evaluation of well-being. Interestingly, performing separate analyses for some Eastern European countries, we find some evidence that reference group's income exerts a positive influence on individual happiness and life satisfaction, which lends support to Hirschman's (1973) 'tunnel effect' conjecture. Therefore, it seems that in these countries reference income does not influence individuals' well-being through social comparisons, but rather

\footnotetext{
${ }^{4}$ It is worth noting that, whilst most studies find that the correlation between happiness and life satisfaction is in the range of 50 to 60 percent (e.g. Diener et al., 1995), other studies report much lower values for some population sub-groups.
} 
through their informational content, which individuals use in order to form expectations about their future economic situation. ${ }^{5}$

The layout of the remainder of the paper is as follows. Section 2 describes the data and the empirical framework. Section 3 presents the empirical findings and discusses their policy implications. Section 4 offers some concluding remarks.

\section{Data and empirical framework}

Our empirical analysis is based on data for nineteen European countries from the first two waves (2003 and 2004) of the European Social Survey (ESS). The European Commission, the European Science Foundation and scientific funding bodies in each of the participating countries fund the ESS jointly. Data on the following 19 countries are analyzed: Austria, Belgium, Czech Republic, Denmark, Finland, Germany, Greece, Hungary, Ireland, Luxembourg, Netherlands, Norway, Poland, Portugal, Slovenia, Spain, Sweden, Switzerland, and the United Kingdom.

The ESS data contains information on happiness and life satisfaction, the dependent variables in our analysis, which allows us to test whether social comparisons and reference groups exert an important influence on individuals' subjective well-being. The question on life satisfaction is formulated as follows: “All things considered, how satisfied are you with your life as a whole nowadays? Please answer using this card, where 0 means extremely dissatisfied and 10 means extremely satisfied." Similarly, the question on happiness is: "Taking all things together, how happy would you say you are?” with responses on a scale 0 to 10 with 0 Extremely Unhappy and 10 Extremely Happy. We use these two variables as dependent

\footnotetext{
${ }^{5}$ Senik (2004) is the first study to test formally the 'tunnel effect' hypothesis using large-scale data.
} 
variables in our regressions.

Due to the ordinal nature of the happiness and life satisfaction variables, we estimate ordered probit models, assuming that a latent and continuous measure of the dependent variable, a proxy for utility, is given by:

$$
S_{i}^{*}=\beta^{\prime} z_{i}+e_{i},
$$

where $z_{i}$ is a vector of explanatory variables describing individual and firm characteristics, $\beta$ is a vector of parameters to be estimated and $e_{i}$ is a random error term, normally distributed.

The observed and coded discrete dependent variable $S_{i}$ is determined from the model as follows:

$$
S_{i}=\left\{\begin{array}{ccc}
0 & \text { if }-\infty \leq S_{i}^{*} \leq \mu_{1} \\
1 & \text { if } & \mu_{1}<S_{i}^{*} \leq \mu_{2} \\
2 & \text { if } & \mu_{2}<S_{i}^{*} \leq \mu_{3} \\
& & \cdot \\
& \cdot \\
10 & \text { if } & \mu_{10}<S_{i}^{*} \leq \infty
\end{array}\right.
$$

where $\mu_{i}$ represents thresholds to be estimated (along with the parameter vector $\beta$ ). Positive signs for the estimated parameters $\beta$ indicate higher levels of life satisfaction as the value of the associated variable increases. ${ }^{6}$

The ESS data provides also information on a rich set of standard demographic and labour market characteristics that we use as controls in our life satisfaction and happiness regressions. Such controls include personal characteristics, education,

\footnotetext{
${ }^{6}$ For a discussion of the ordered probit model see McKelvey and Zavoina (1975)
} 
labour force status, establishment size, income and health. Information on past unemployment experience is also used to evaluate whether individuals' perceptions about their current economic situation is influenced by past income shocks, usually associated with unemployment. To measure reference income, our main variable of interest, we use two main proxies. First, following McBride (2001), we define the reference group to include all individuals who are in the age range of 5 years younger and 5 years older than the individual concerned (Proxy 1). Second, we define the reference group to contain all individuals with a similar education level, inside the same age bracket, and living in the same country, as suggested by Ferrer-i-Carbonnell (2005). Education is divided into five different categories according to the highest educational attainment: up to primary school, lower secondary, upper secondary, post secondary but not tertiary and tertiary and beyond. The age brackets are: younger than $25,25-34,35-44,45-65$, and 66 or older. We refer to this measure of reference income as Proxy 2. ${ }^{7}$ The definitions and sample means of all variables used in our analysis are in Appendix 1. We limit our sample to full-time salaried employees, which yields 30,285 observations fairly equally split between 2002 and 2004 . Appendix 2 shows the number of observations by country and by year.

Figure 1 shows the distribution of happiness and life satisfaction for the 19 European countries under consideration. Clearly there is a close, but non-exact, correlation between happiness and life satisfaction. Both measures indicate a high level of happiness or satisfaction among the respondents from the 19 participating EU countries, with the mode well-being score of 8 . The distribution of happiness is also clearly skewed towards the high end. Moreover, there is little variation in the expression of happiness over the two reporting periods.

\footnotetext{
${ }^{7}$ These measures of reference income are based on a "cell means” approach. An alternative approach
} 
However, once we examine the level of happiness across countries, then some variations start to emerge, as shown in Figure 2. Using either measure, Denmark achieved the highest score at over 8, whilst Greece, Hungary, Poland and Portugal recorded the lowest scores during the reporting periods. In general, Western European countries score higher than Eastern European ones. Such differences are apparent also in Appendix 3, reporting the mean scores of life satisfaction and happiness. Although the comparability of responses across individuals in different countries might call for caution in interpreting these stylised facts, mounting evidence supports the use and reliability of subjective well-being variables in economic research (see Clark et al., 2006). As Clark (2005) asserts, a small body of research in economics and psychology finds evidence of causation between the cross-sectional distribution of subjective scores and subsequent labour market outcomes.

\section{Empirical findings}

Table 1 reports the results for life satisfaction regressions. Column (1) reports the regression results with reference income being excluded as an explanatory variable. As the estimated coefficients in column 1 show, the results are generally consistent with those of previous studies and hardly surprising. As the estimated coefficients reveal, men tend to report lower satisfaction than women, while life satisfaction exhibits a U-shaped relationship with age. This is a pattern, well documented in the literature, reflecting life-cycle aspects of individuals' social, family and economic circumstances (e.g. Alesina et al., 2004; Blanchflower and Oswald, 2004; 
Blanchflower and Oswald, 2006). ${ }^{8}$ Being married has a positive effect on life satisfaction, while the opposite is true for divorce, separation and widowhood. The results also reveal a negative effect of the presence of children on life satisfaction. As expected, good health has a significant positive effect. There is some weak evidence that higher education qualifications tend to exert a negative impact on life satisfaction, with the estimated coefficient of 'Post tertiary' education being negative and statistically significant. This result is similar to the findings in earlier studies such as Campbell et al. (1976) and Fernandez and Kulik (1981). A possible explanation could be that education raises aspirations not easily fulfilled. There is no clear pattern in the link between life satisfaction and firm size.

Past unemployment has a positive effect on life satisfaction, with such an effect being stronger for more recently experienced unemployment (in the last twelve months) as opposed to unemployment in the more distant past (in the last five years). It is possible that the well-being of the currently employed exceeds their reference or aspiration value, which may have been reduced by the recently experienced unemployment shock. ${ }^{9}$ As countries with generous social welfare systems dominate our sample, the positive effect of unemployment on happiness may reflect also the influence of social welfare systems on individual well-being during the period of unemployment. For example, in countries with poor social protection, unemployment is expected to have a stronger negative impact on individual wellbeing, a conjecture supported by running separate regressions for sub-groups of countries with different levels of social protection. The effect of recent unemployment (in the past 12

\footnotetext{
${ }^{8}$ For a review of the factors that affect subjective well-being over the life cycle see Easterlin (2006).

${ }^{9}$ Clark et al (2001) find that unemployment experience in the past three years reduces life satisfaction of the currently employed (i.e. unemployment 'scars' psychologically). However, they also find some evidence of habituation - people may get used to unemployment. According to Lucas et al. (2004), adaptation to unemployment is slow and incomplete.
} 
months) on well-being is strongly positive and statistically significant for the Scandinavian countries, and weakly positive but statistically insignificant for the Western European countries. In contrast, such an effect is very weakly positive and statistically insignificant for the Southern European countries, and strongly negative and statistically significant for the Eastern European countries. Differences regarding the negative well-being effect of unemployment across European countries can be attributed also to differences in the extent to which unemployment across these countries has become a social norm. ${ }^{10}$

Higher absolute income is associated with higher life satisfaction, with a clear pattern of the estimated coefficients for incomes above the income bracket above 350460 Euros (the omitted category) being positive and statistically significant, while the coefficients for incomes below the 350 Euros being negative. Therefore, it appears that, across Europe, “income buys happiness”. ${ }^{11}$ In columns (2) and (3), we reexamine this conjecture by controlling for relative income, and to assess the extent at which comparison effects may weaken the link between income and happiness. As shown in column (2), reference income (Proxy 1) has a negative and significant effect, suggesting that comparison effects in life satisfaction are present. The same result emerges using an alternative proxy for relative income (Proxy 2) in column (3).

In Table 2, we repeat the analysis using self-reported happiness scores as the dependent variable instead of life satisfaction. Results are generally similar to those for life satisfaction in Table 1, with only slight differences in the size of the estimated

\footnotetext{
${ }^{10}$ This is a point that Clark (2005) makes convincingly with evidence that supports the view that the negative well-being effect of unemployment is less severe, when unemployment has become more socially acceptable. Our findings of a significantly negative effect of unemployment on happiness for Eastern European countries are very similar to the findings in Hayo and Seifert (2003).

${ }^{11}$ Focusing on Eastern European countries, Hayo and Seifert (2003) find a strong link between life satisfaction and subjective economic well-being.
} 
coefficients. It is worth noting, for example, that income coefficients in the happiness regression tend to be 'smaller' than those in the life satisfaction regressions. This is consistent with the view that happiness is " a broader” concept than life satisfaction, with perhaps the impact of economic factors on happiness being mitigated by the influence of factors affecting individuals' well-being in the life domain. In this respect, the larger coefficient of being married (a positive life event/state) in the happiness regression compared to that in the life satisfaction regression is not surprising. In the same spirit, the negative coefficient for the presence of children is smaller than that in Table 1. Interestingly, comparison effects are stronger in the case of happiness than in the case of life satisfaction regressions. As reported in columns (2) and (3), the estimated coefficients of reference income are significantly higher than those in Table 1.

When repeating the analysis, by limiting our sample to the Eastern European countries (see Table 3) any evidence of comparison effects seems to disappear. This effect is more prominent in Table 4, where we re-estimate the happiness regression for the Eastern European countries. In this case, there is some evidence not only that comparison effects disappear, but also that reference income exerts a positive and significant effect on happiness, suggesting the presence of a "tunnel effect" (see Senic, 2004). The rapid growth of income that certain segments of the population experienced during the period of economic transition increased the expectations of the remainder of the population for higher incomes in the future. In a sense, pockets of high income and prosperity in the economy offer an optimistic outlook for those who are yet to catch up. As Hayo and Seifert (2003) highlight, during the early 1990s, there was a general climate of optimism among Eastern Europeans that their economic situation would improve, or at least not deteriorate, in the next five years. 
During these early years of reform, catching-up with the well-being levels of industrialised countries would dominate any relative income effects. Therefore, one should expect that such "tunnel effects" might be short-lived as those at the lower end of the income distribution realise that the gap between their economic position and that of the high earners widens without any prospects of ever catching up with them. If this conjecture is valid, then in the economies of transition in Eastern Europe we should expect 'tunnel effects' to be more prominent during the early years of economic reform and starting to weaken as time passes by in a non-monotonic fashion. Given that our sample is based on data almost ten years after the excommunist Eastern European countries embarked on a programme of economic reforms towards free market economies, evidence of 'tunnel effects' might not be as strong as 'tunnel effects' in the earlier years of economic transition.

\section{Conclusions}

In recent years, support for the notion that reference values are important in affecting individuals' behaviour has become widespread both in the psychology and the economics literature. Economists, in particular, tend to agree that the decision makers evaluate the options available to them not on the basis of absolute values of wealth or welfare but on relative values instead, implying that utility is relative in nature. Van de Stadt et. al. (1985) provide some early evidence consistent with the relative utility hypothesis, while, more recently, Clark and Oswald (1996) show that utility depends on income relative to some reference or comparison income. In the same vein, FerrerI-Carbonell (2005) provides evidence that reference income is as important as own income for individuals’ happiness. 
In this paper, we have re-examined the link between income and subjective well-being for a number of European countries, paying particular attention to whether relative income is indeed an important determinant of subjective well-being. Our results tend to support the relative utility hypothesis, in that the income of a reference group exerts a negative effect on well-being, even after controlling for absolute income and other personal and demographic characteristics. More intriguing, perhaps, is the fact that such social comparison effects tend to disappear when we limit our analysis to the Eastern European countries. In the case of Eastern Europe, reference income has a positive effect on happiness, consistently with the presence of a 'tunnel effect'. To the extent that the 'pursuit of happiness' enters the political agenda, our results highlight the existence of a clear wedge between Western and Easter European countries that can have important implications for the design of welfare reforms and income redistribution policies. If, as our results seem to imply, an increasing income gap between the rich and poor reduces well-being due to social comparisons, alleviating income inequality moves higher up in the policy agenda. In contrast, if higher inequality raises the expectations of the poor that they are to enjoy higher incomes in the future (i.e. 'tunnel effect'), then increased income inequality during rapid growth at the early stages of reforms becomes socially and politically more acceptable. 


\section{References}

Abel, A.B. (1990). Asset Prices under Habit Formation and Catching up with the Joneses. American Economic Review, 80(2), 38-42.

Alesina, A., DiTella, R., \& MacCulloch, R. (2004). Inequality and happiness: Are Europeans and Americans different? Journal of Public Economics, 88, 20092042.

Blanchflower, D., \& Oswald, A. (2004). Wellbeing over time in Britain and the USA. Journal of Public Economics, 88, pp. 1359-1386.

Blanchflower, D., \& Oswald, A. (2006). Is Wellbeing U-shaped over the life cycle?, mimeo, University of Warwick.

Brickman, P., \& Campbell, D. (1971). Hedonic relativism and planning the good society. In: Appley, M.H. (Ed.): Adaptation-level theory: A symposium. Academic Press, New York.

Brickman, P., Coates, D., \& Janoff-Bulman, R. (1978). Lottery winners and accident victims: is happiness relative? Journal of Personality and Social Psychology 36, 917-927.

Campbell, J., \& Cochrane, J. H. (1999). By Force of Habit: A Consumption-Based Explanation of Aggregate Stock Market Behavior. Journal of Political Economy, 107(2), 205 - 51.

Campbell, A., Converse, P.E. \& Rogers, W.L. (1976). The Quality of American Life: Perceptions, Evaluations, and Satisfactions, Russel Sage, New York.

Clark, A. (2005). Your money or your life: Changing job quality in OECD countries, British Journal of Industrial Relations 43, 377-400.

Clark, A. \& Oswald, A. (1996). Satisfaction and comparison income. Journal of Public Economics, 61, 359-81. 
Clark, A. (2000). Is Utility Absolute or Relative? Revue Economique 51: 459-71.

Clark, A., Frijters, P., \& Shields, M. (2006). Income and happiness: Evidence, Explanations and Economic Implications, working paper, PSE, Paris.

Clark, A., Georgellis, Y., \& Sanfey, P. (2001). Scarring: The Psychological Impact of Past Unemployment. Economica, 68 (270): 221-42.

Cummings, R. (1998). The second approximation to an international standard for life satisfaction. Social Indicators Research, 43, 307-334.

Diener, E., Sandvik, E., Seidlitz, L., \& Diener, M. (1993). The relationship between income and subjective wellbeing: Relative or absolute? Social Indicators Research, 28, 195-223.

Diener, E., Diener, M., \& Diener, C. (1995). Factors predicting the subjective wellbeing of nations. Journal of Personality and Social Psychology, 69, 851-864.

Duesenberry, J. S. (1949). Income, Saving and the Theory of Consumer Behavior, Harvard, University of Harvard Press.

Easterlin, R. (1974). Does economic growth improve the human lot? Some empirical evidence. In P. A. David \& M. W. Reder (Eds), Nations and households in economic growth (pp.89-125). Academic Press.

Easterlin, R. (1995). Will raising the income of all increase the happiness of all? Journal of Economic Behavior and Organization, 27(1): 35-47.

Easterlin, R. (2001). Income and happiness: Toward a unified theory. Economic Journal 111, 464-84.

Easterlin, R. (2005). A puzzle for adaptive theory. Journal of Economic Behavior and Organization 56, 513-21. 
Easterlin, R. (2006). Life cycle happiness and its sources: Intersections of psychology, economics and demography. Journal of Economic Psychology 27, 463-482.

Fernandez, R., Kulik, J. (1981). A Multilevel Model of Life satisfaction: Effects of Individual Characteristics and Neighborhood Composition. American Sociological Review, 46, 840-50.

Ferrer-i-Carbonell, A. (2005). Income and well being: an empirical analysis of the comparison income effect. Journal of Public Economics, 89, 997-1019.

Frey, B., \& Stutzer, A. (2000). Happiness, economy and institutions. Economic Journal, 110, 918-938.

Frijters, P., Haisken-DeNew, J.P., \& Shields, M.A. (2004). Money Does Matter! Evidence from Increasing Real Income and Life Satisfaction in East Germany Following Reunification. American Economic Review, 94(3), 730-740.

Furher, J.C. (2000). Habit Formation in Consumption and Its Implications for Monetary-Policy Models. American Economic Review, 90(3), 367-90.

Gundelach, P., \& Kreiner, S. (2004). Happiness and life satisfaction in advanced European countries. Cross-Cultural Research, 38(4): 359-386.

Hayo, B., \& Seifert, W. (2003). Subjective economic well-being in Eastern Europe. Journal of Economic Psychology, 24, 329-348.

Heady, B. (1991). An economic model of subjective well-being: Integrating economic and psychological theories. Social Indicators Research, 28, 97116.

Hirschman, A. (1973). The changing tolerance for income inequality in the course of economic development. Quarterly Journal of Economics 87(4), 544-566. 
Kahneman, D., \& Tversky, A. (1979). Prospect theory: an analysis of decision under risk. Econometrica, 47, 263-291.

Kahneman, D., \& Krueger, A. (2006). Developments in the Measurement of Subjective Well-being. Journal of Economic Perspectives, 20(1), 3-24.

Lucas, R., Clark, A., Georgellis, Y., \& Diener, E. (2004). Unemployment alters the set point of life satisfaction. Psychological Science, 15(1), 8-13.

Mas, A. (2006). Pay, reference points, and police performance. Quarterly Journal of Economics, 121(3): 783-821.

McBride, M. (2001). Relative-income effects on subjective well-being in the crosssection. Journal of Economic Behavior and Organization, 45, 251-78.

McKelvey, R., \& Zavoina, W. (1975). A statistical model for the analysis of ordinal level dependent variables. Journal of Mathematical Sociology, 4, 103-20.

Michalos, A. C. (1991). Global report on student well-being, Vol.: Life Satisfaction and Happiness (Springer Verlag, New York).

Rizzo, J., \& Zeckhauser, R. (2003). Reference incomes, loss aversion, and physician behavior. Review of Economics and Statistics, 85, 909-22.

Rojas, M. (2007). Heterogeneity in the relationship between income and happiness: A conceptual-referent-theory explanation. Journal of Economic Psychology, 28, 1-14.

Senic, C. (2004). When information dominates comparison: Learning from Russian subjective panel data. Journal of Public Economics, 88, 2099-2123.

Solberg, E.C., Diener, E., Wirtz, D., \& Lucas, R. (2002). Wanting, having, and satisfaction: Examining the role of desire discrepancies in satisfaction with income. Journal of Personality and Social Psychology 83, 725-34. 
Stutzer, A. (2004). The role of income aspirations in individual happiness. Journal of Economic Behavior and Organization, 54, 89-109.

Van de Stadt, H., Kapteyn, A., \& van de Geer, S. (1985). The relativity of utility: Evidence from panel data. Review of Economics and Statistics, 67(2), 179-87. Van Praag, B.M.S., (1971). The welfare function of income in Belgium: An empirical investigation. European Economic Review, 2, 337-69.

Van Praag, B.M.S. \& Ferrer-i-Carbonell, A. (2004), Happiness quantified: A satisfaction calculus approach. Oxford University Press.

Van Praag, B.M.S. \&, Kapteyn, A. (1973). Further evidence on the individual welfare function of income: An empirical investigation in the Netherlands. European Economic Review, 4, 33-62. 
Table 1: Life satisfaction regressions (Ordered probit)

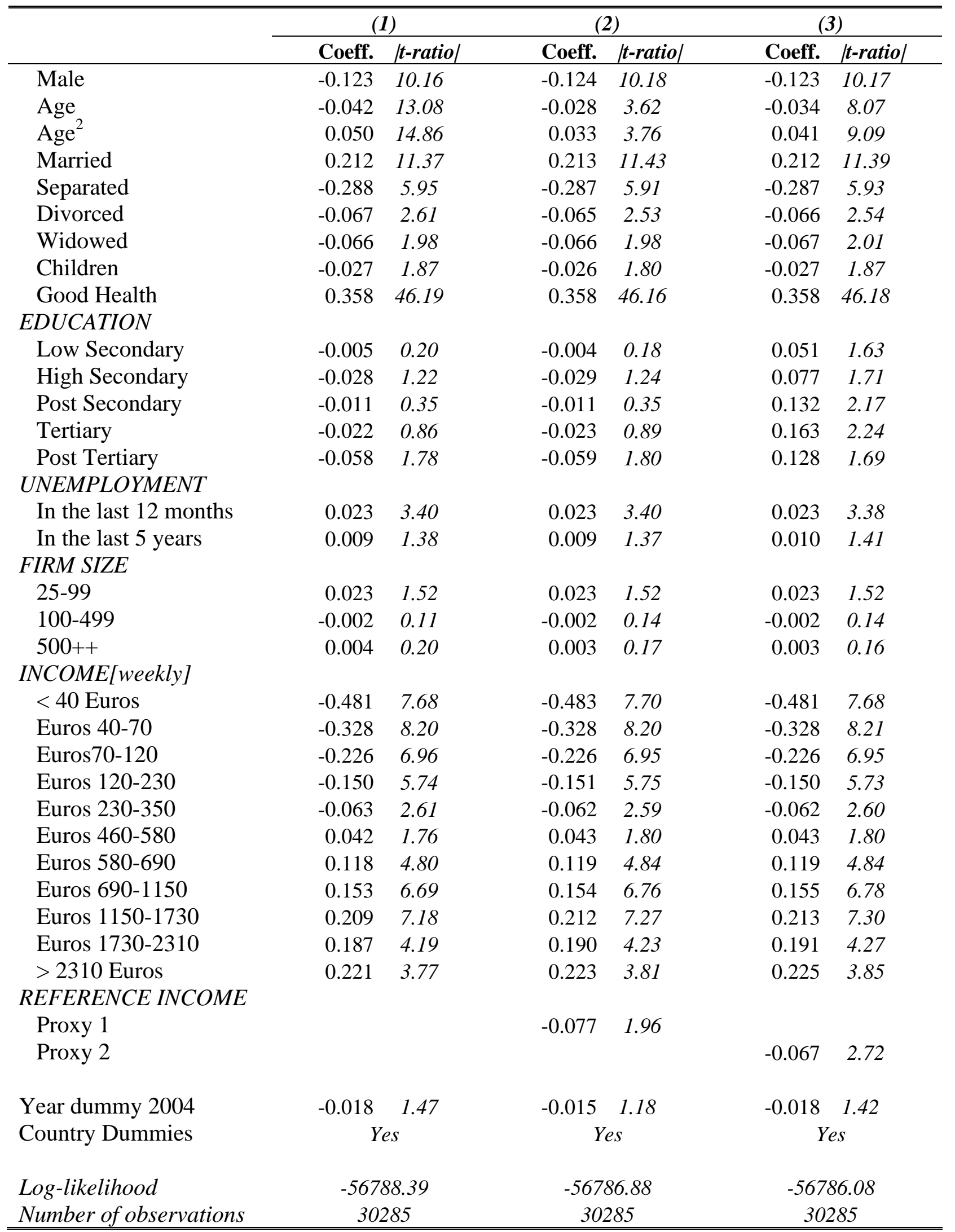

Notes: 
Table 2: Happiness regressions (Ordered probit)

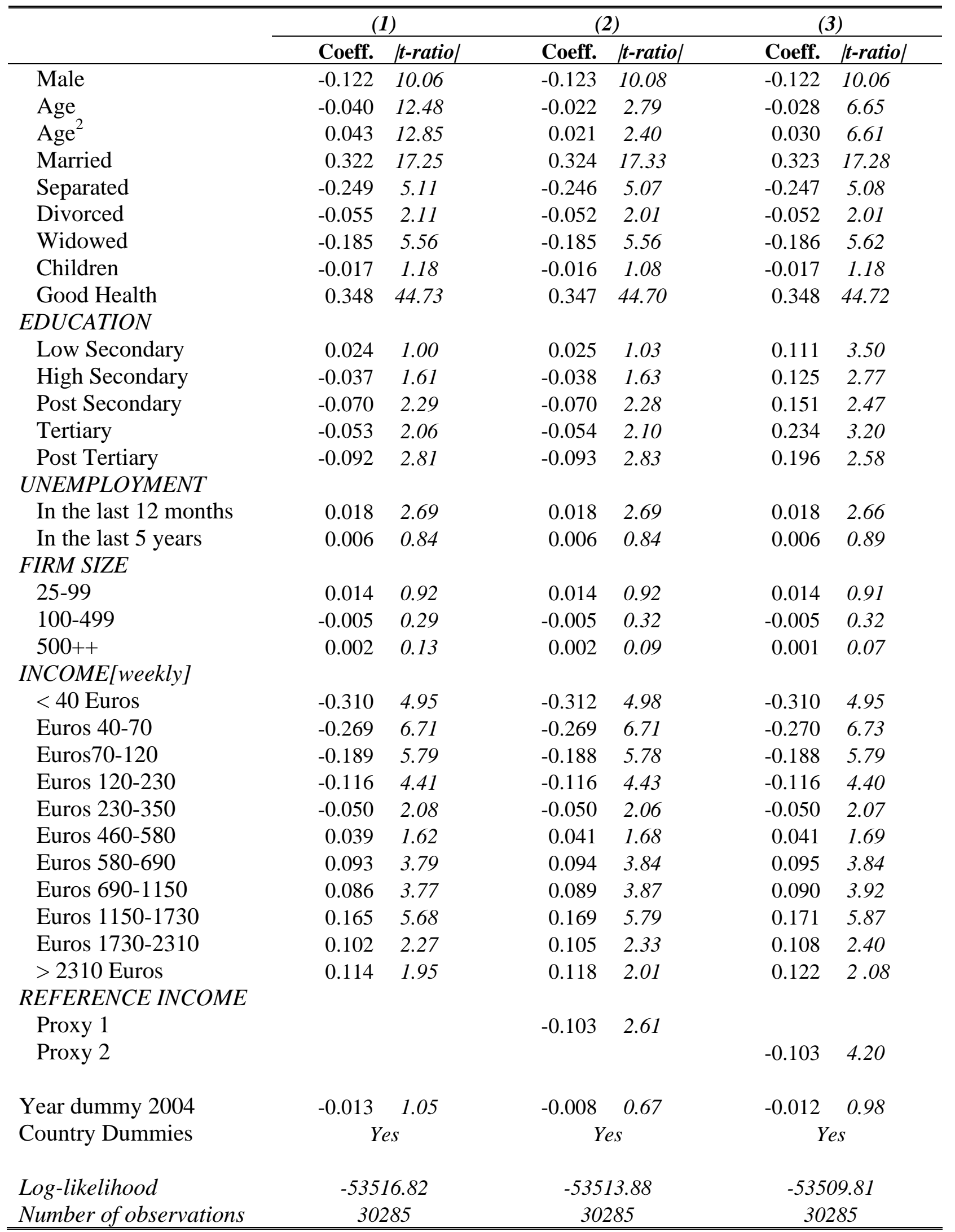

Notes: 
Table 3: Life satisfaction regressions: Eastern Europe (Ordered probit)

\begin{tabular}{|c|c|c|c|c|c|c|}
\hline & \multicolumn{2}{|c|}{ (1) } & \multicolumn{2}{|c|}{ (2) } & \multicolumn{2}{|c|}{ (3) } \\
\hline & Coeff. & |t-ratio| & Coeff. & |t-ratio| & Coeff. & t-ratio \\
\hline \multicolumn{7}{|l|}{ INCOME[weekly] } \\
\hline$<40$ Euros & -0.705 & 7.18 & -0.708 & 7.21 & -0.704 & 7.17 \\
\hline Euros 40-70 & -0.458 & 6.26 & -0.459 & 6.27 & -0.458 & 6.26 \\
\hline Euros70-120 & -0.279 & 4.23 & -0.279 & 4.22 & -0.279 & 4.23 \\
\hline Euros 120-230 & -0.172 & 2.76 & -0.172 & 2.76 & -0.172 & 2.76 \\
\hline Euros 230-350 & -0.037 & 0.55 & -0.036 & 0.54 & -0.037 & 0.55 \\
\hline Euros 460-580 & -0.023 & 0.25 & -0.023 & 0.25 & -0.023 & 0.25 \\
\hline Euros 580-690 & 0.064 & 0.52 & 0.066 & 0.53 & 0.064 & 0.51 \\
\hline Euros 690-1150 & -0.009 & 0.07 & -0.011 & 0.09 & -0.009 & 0.07 \\
\hline Euros 1150-1730 & -0.384 & 1.64 & -0.393 & 1.68 & -0.384 & 1.64 \\
\hline Euros 1730-2310 & 0.421 & 1.23 & 0.429 & 1.25 & 0.421 & 1.23 \\
\hline > 2310 Euros & -0.342 & 0.58 & -0.332 & 0.56 & -0.342 & 0.58 \\
\hline \multicolumn{7}{|l|}{ REFERENCE INCOME } \\
\hline Proxy 1 & & & 0.096 & 0.99 & & \\
\hline Proxy 2 & & & & & 0.008 & 0.87 \\
\hline Log-likelihood & \multicolumn{2}{|c|}{-10214.02} & \multicolumn{2}{|c|}{-10213.53} & \multicolumn{2}{|c|}{-10214.02} \\
\hline Number of observations & \multicolumn{2}{|c|}{4913} & \multicolumn{2}{|c|}{4913} & \multicolumn{2}{|c|}{4913} \\
\hline
\end{tabular}

Notes: Other regressors as in Table 1. 
Table 4: Happiness regressions: Eastern Europe (Ordered probit)

\begin{tabular}{|c|c|c|c|c|c|c|}
\hline & \multicolumn{2}{|c|}{ (1) } & \multicolumn{2}{|c|}{$(2)$} & \multicolumn{2}{|c|}{ (3) } \\
\hline & Coeff. & $\mid$ t-ratio $\mid$ & Coeff. & $\mid$ t-ratio| & Coeff. & $\mid$ t-ratio $\mid$ \\
\hline \multicolumn{7}{|l|}{ INCOME[weekly] } \\
\hline$<40$ Euros & -0.349 & 3.57 & -0.349 & 3.57 & -0.353 & 3.61 \\
\hline Euros 40-70 & -0.235 & 3.21 & -0.235 & 3.21 & -0.236 & 3.22 \\
\hline Euros70-120 & -0.155 & 2.34 & -0.155 & 2.34 & -0.155 & 2.34 \\
\hline Euros 120-230 & -0.090 & 1.44 & -0.090 & 1.44 & -0.089 & 1.42 \\
\hline Euros 230-350 & 0.002 & 0.03 & 0.002 & 0.03 & 0.002 & 0.03 \\
\hline Euros 460-580 & 0.157 & 1.69 & 0.157 & 1.69 & 0.158 & 1.71 \\
\hline Euros 580-690 & 0.088 & 0.71 & 0.088 & 0.71 & 0.092 & 0.74 \\
\hline Euros 690-1150 & 0.080 & 0.61 & 0.080 & 0.62 & 0.079 & 0.61 \\
\hline Euros 1150-1730 & -0.144 & 0.61 & -0.144 & 0.61 & -0.146 & 0.62 \\
\hline Euros 1730-2310 & 0.411 & 1.20 & 0.410 & 1.19 & 0.412 & 1.20 \\
\hline$>2310$ Euros & -0.248 & 0.42 & -0.248 & 0.42 & -0.235 & 0.40 \\
\hline \multicolumn{7}{|l|}{ REFERENCE INCOME } \\
\hline Proxy 1 & & & 0.065 & 1.65 & & \\
\hline Proxy 2 & & & & & 0.073 & 1.63 \\
\hline Log-likelihood & \multicolumn{2}{|c|}{-9623.48} & \multicolumn{2}{|c|}{-9622.48} & \multicolumn{2}{|c|}{-9622.84} \\
\hline Number of observations & \multicolumn{2}{|c|}{4913} & \multicolumn{2}{|c|}{4913} & \multicolumn{2}{|c|}{4913} \\
\hline
\end{tabular}

Notes: Other regressors as in Table 1. 


\begin{tabular}{|c|c|c|c|}
\hline & \multirow[t]{2}{*}{ Definition } & \multicolumn{2}{|c|}{ Mean } \\
\hline & & 2002 & 2004 \\
\hline Male & Dummy Variable: 1=Male; 0 otherwise. & 0.499 & 0.493 \\
\hline Age & Age in years. & 45.853 & 48.238 \\
\hline Married & Dummy Variable: 1=Married; 0 otherwise. & 0.616 & 0.611 \\
\hline Separated & Dummy Variable: 1=Separated; 0 otherwise & 0.016 & 0.016 \\
\hline Divorced & Dummy Variable: 1=Divorced; 0 otherwise. & 0.087 & 0.090 \\
\hline Widowed & Dummy Variable: 1=Widowed; 0 otherwise. & 0.051 & 0.051 \\
\hline Never Married & Dummy Variable: 1=Never Married; 0 otherwise. & 0.227 & 0.229 \\
\hline Children & Dummy Variable: 1=Children in household; 0 otherwise. & 0.466 & 0.457 \\
\hline Good Health & $\begin{array}{l}\text { Subjective General Health, Ordinal Variable: 1=Very Bad, } \\
\text { 2=Bad, 3=Fair, 4=Good, 5=Very Good }\end{array}$ & 3.874 & 3.888 \\
\hline \multicolumn{4}{|c|}{ - the } \\
\hline Primary & Dummy Variable: 1=Primary; 0 otherwise. & 0.116 & 0.132 \\
\hline Low Secondary & Dummy Variable: 1=Low Secondary; 0 otherwise. & 0.204 & 0.177 \\
\hline High Secondary & Dummy Variable: 1=High Secondary; 0 otherwise. & 0.377 & 0.392 \\
\hline Post Secondary & Dummy Variable: 1=Post Secondary; 0 otherwise. & 0.086 & 0.062 \\
\hline Tertiary & Dummy Variable: 1=Tertiary; 0 otherwise. & 0.160 & 0.193 \\
\hline Post Tertiary & Dummy Variable: $1=$ Post Tertiary; 0 otherwise. & 0.061 & 0.056 \\
\hline \multicolumn{4}{|l|}{ UNEMPLOYMENT } \\
\hline In the last 12 months & Number of periods of unemployment within last 12 months. & 4.615 & 4.606 \\
\hline In the last 5 years & Number of periods of unemployment within last 5 years. & 4.734 & 4.615 \\
\hline \multicolumn{4}{|l|}{ FIRM SIZE } \\
\hline Less than 25 & Dummy Variable: 1= Less than 25 employees; 0 otherwise & 0.198 & 0.210 \\
\hline $25-99$ & Dummy Variable: 1= Between 25-99 employees; 0 otherwise. & 0.245 & 0.253 \\
\hline $100-499$ & Dummy Variable: 1= Between 100-499 employees; 0 otherwise. & 0.198 & 0.188 \\
\hline $500++$ & Dummy Variable: 1= More than 500 employees; 0 otherwise. & 0.158 & 0.136 \\
\hline \multicolumn{4}{|l|}{$\begin{array}{l}\text { INCOME [weekly] } \\
\text { (Household's Total Net } \\
\text { Income, All Sources) }\end{array}$} \\
\hline$<40$ Euros & Dummy Variable: 1=Less than 40 Euros; 0 otherwise. & 0.015 & 0.005 \\
\hline Euros $40-70$ & Dummy Variable: 1=Between 40-70 Euros; 0 otherwise. & 0.040 & 0.026 \\
\hline Euros70-120 & Dummy Variable: 1=Between 70-120 Euros; 0 otherwise. & 0.064 & 0.054 \\
\hline Euros $120-230$ & Dummy Variable: 1=Between 120-230 Euros; 0 otherwise. & 0.107 & 0.106 \\
\hline Euros 230-350 & Dummy Variable: 1=Between 230-350 Euros; 0 otherwise. & 0.125 & 0.113 \\
\hline Euros 350-460 & Dummy Variable: 1=Between 350-460 Euros; 0 otherwise. & 0.125 & 0.124 \\
\hline Euros $460-580$ & Dummy Variable: 1=Between 460-580 Euros; 0 otherwise. & 0.121 & 0.113 \\
\hline Euros 580-690 & Dummy Variable: 1=Between 580-690 Euros; 0 otherwise. & 0.111 & 0.122 \\
\hline Euros 690-1150 & Dummy Variable: 1=Between 690-1150 Euros; 0 otherwise. & 0.184 & 0.208 \\
\hline Euros $1150-1730$ & Dummy Variable: 1=Between 1150-1730 Euros; 0 otherwise. & 0.072 & 0.086 \\
\hline Euros $1730-2310$ & Dummy Variable: 1=Between 1730-2310 Euros; 0 otherwise. & 0.020 & 0.024 \\
\hline$>2310$ Euros & Dummy Variable: 1=More than 2310 Euros; 0 otherwise. & 0.010 & 0.013 \\
\hline \multirow{2}{*}{\multicolumn{4}{|c|}{$\begin{array}{l}\text { REFERENCE } \\
\text { INCOME }\end{array}$}} \\
\hline & & & \\
\hline Proxy 1 & $\begin{array}{l}\text { All individuals who are in the age range of } 5 \text { years younger and } 5 \\
\text { years older than the individual concerned, (by year by country) }\end{array}$ & 6.347 & 6.368 \\
\hline Proxy 2 & $\begin{array}{l}\text { All individuals with a similar education level, inside the same } \\
\text { age bracket, and living in the same country (by year) }\end{array}$ & 6.428 & 6.464 \\
\hline
\end{tabular}


Appendix 2. ESS 2002-2004: Number of Employees in European Countries

\begin{tabular}{lccc}
\hline \hline COUNTRIES & 2002 & 2004 & Total \\
\hline Austria & 865 & 714 & 1579 \\
Belgium & 821 & 841 & 1662 \\
Switzerland & 1061 & 1084 & 2145 \\
Czech Republic & 424 & 970 & 1394 \\
Germany & 1529 & 1305 & 2834 \\
Denmark & 881 & 783 & 1664 \\
Spain & 341 & 414 & 755 \\
Finland & 1047 & 1082 & 2129 \\
Britain & 634 & 519 & 1153 \\
Hellas & 535 & 383 & 918 \\
Hungary & 437 & 359 & 796 \\
EIRE & 748 & 616 & 1364 \\
Luxemburg & 546 & 608 & 1154 \\
Netherlands & 1335 & 968 & 2303 \\
Norway & 1333 & 1067 & 2400 \\
Poland & 818 & 636 & 1454 \\
Portugal & 515 & 537 & 1052 \\
Sweden & 1144 & 1116 & 2260 \\
Slovenia & 685 & 584 & 1269 \\
\hline Total & $\mathbf{1 6 5 7 7}$ & $\mathbf{1 3 7 0 8}$ & $\mathbf{3 0 2 8 5}$ \\
\hline \hline
\end{tabular}


APPENDIX 3. Average Life Satisfaction and Happiness

\begin{tabular}{|c|c|c|c|c|c|c|}
\hline \multirow[b]{2}{*}{ COUNTRIES } & \multicolumn{3}{|c|}{ LIFE SATISFACTION } & \multicolumn{3}{|c|}{ HAPPINESS } \\
\hline & 2002 & 2004 & & 2002 & 2004 & \\
\hline Austria & 7.570 & 7.323 & $* * *$ & 7.608 & 7.437 & $*$ \\
\hline Belgium & 7.471 & 7.374 & $* * *$ & 7.782 & 7.704 & $* *$ \\
\hline Switzerland & 7.956 & 7.977 & & 7.986 & 8.036 & \\
\hline Czech Republic & 6.296 & 6.318 & $* *$ & 6.710 & 6.782 & $*$ \\
\hline Germany & 6.780 & 6.699 & $* *$ & 7.144 & 7.091 & $*$ \\
\hline Denmark & 8.482 & 8.504 & & 8.359 & 8.344 & \\
\hline Spain & 6.904 & 7.165 & $* *$ & 7.268 & 7.332 & $*$ \\
\hline Finland & 7.891 & 7.980 & $*$ & 8.035 & 8.059 & $*$ \\
\hline Britain & 7.012 & 7.001 & $*$ & 7.517 & 7.483 & \\
\hline Hellas & 6.219 & 6.346 & * & 6.390 & 6.702 & $* * *$ \\
\hline Hungary & 5.519 & 5.539 & * & 6.244 & 6.319 & $* * *$ \\
\hline Ireland & 7.459 & 7.687 & $* *$ & 7.893 & 7.936 & $* * *$ \\
\hline Luxembourg & 7.751 & 7.666 & $*$ & 7.878 & 7.698 & $* *$ \\
\hline Netherlands & 7.616 & 7.434 & * & 7.791 & 7.649 & $*$ \\
\hline Norway & 7.783 & 7.665 & $*$ & 7.897 & 7.900 & \\
\hline Poland & 5.754 & 6.122 & $* * *$ & 6.383 & 6.658 & $* *$ \\
\hline Portugal & 5.653 & 5.408 & $* *$ & 6.773 & 6.439 & $* *$ \\
\hline Sweden & 7.786 & 7.860 & $* *$ & 7.873 & 7.854 & $*$ \\
\hline Slovenia & 6.494 & 6.911 & $* *$ & 6.900 & 7.215 & $* *$ \\
\hline
\end{tabular}


Figure 1.

The distribution of happiness and life satisfaction scores
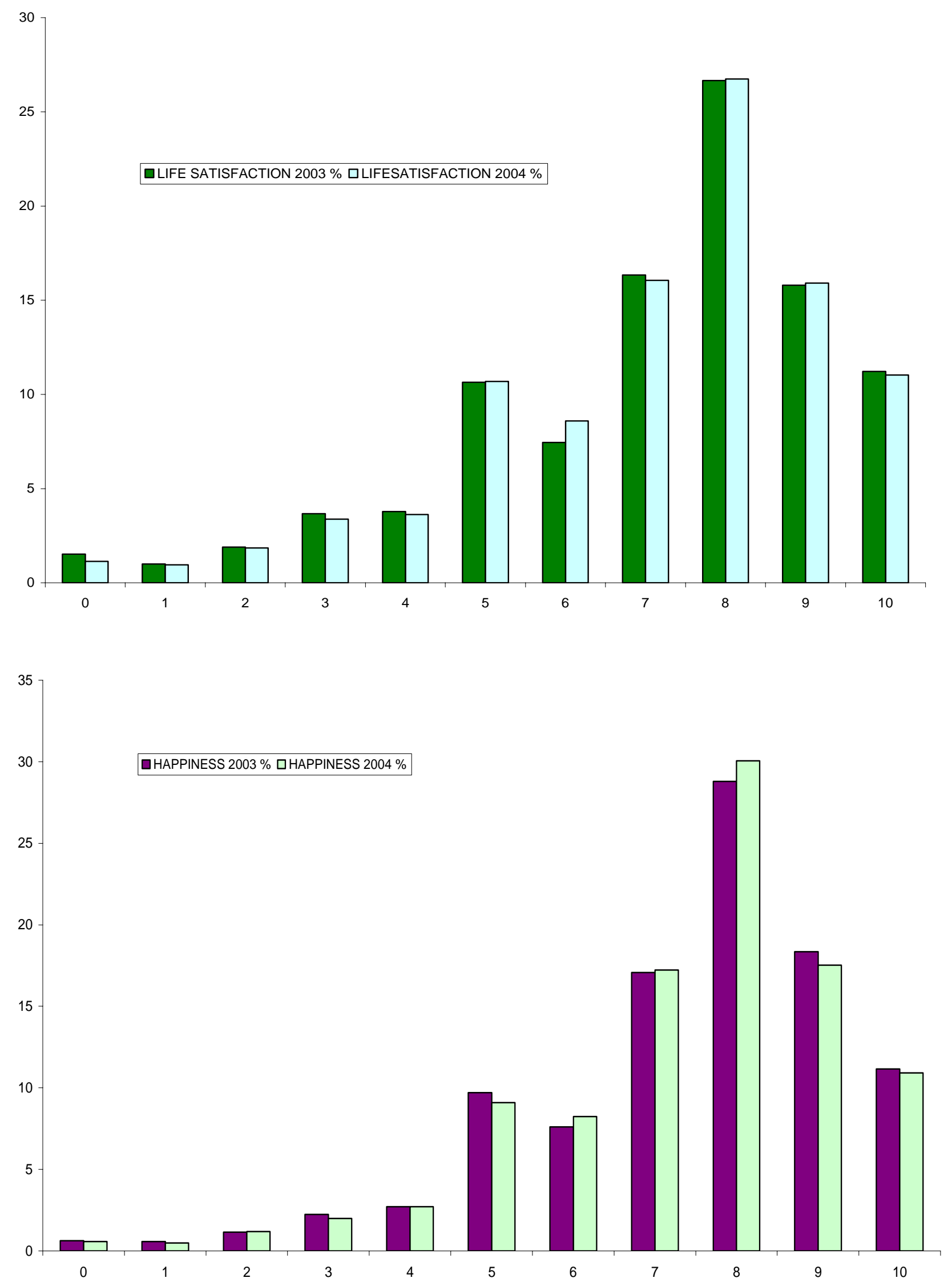
Figure 2.

Income and subjective well-being across Europe
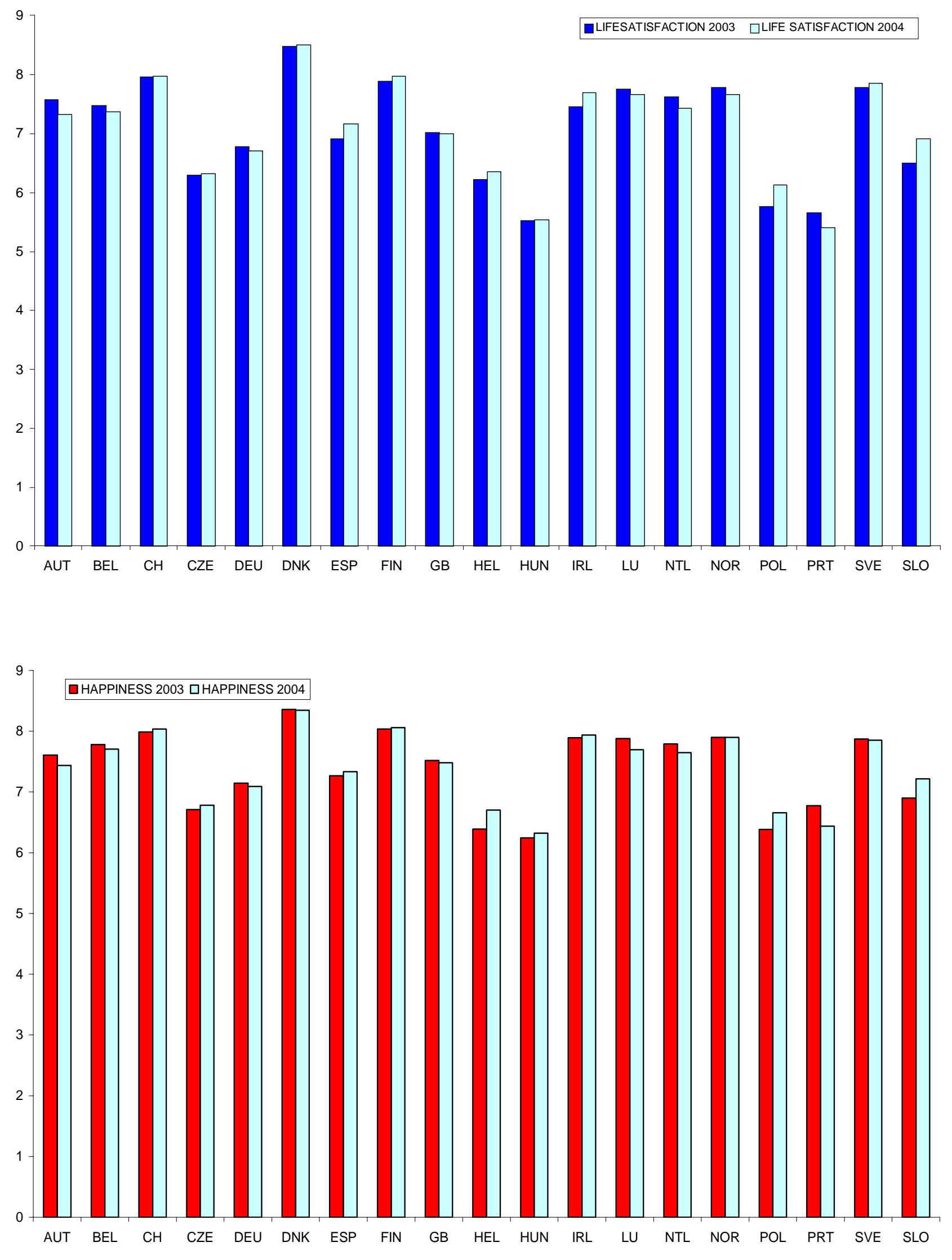